\title{
PENINGKATAN KINERJA GURU DALAM PEMBELAJARAN DI KELAS MELALUI SUPERVISI AKADEMIK DI SMP NEGERI 3 KUALA MANDOR B
}

\author{
Karim Damanik \\ Kepala SMP Negeri 3 Kuala Mandor B Kabupaten Kubu Raya \\ Email :karimdamanik@yahoo.co.id
}

\begin{abstract}
This research is a School Action Research. The subjects of this study were the teachers who taught at SMP Negeri 3 Kuala Mandor B. This research took place in 2 cycles. Each cycle consists of one meeting, Data collection techniques using observation, and documentation. The type of data collected is observational data on teacher learning outcomes in class. The School action research conducted in these two cycles is considered successful if there is an increase in teacher performance reaching $85 \%$ of teachers who have achieved mastery with an average grade of 75. Based on the results of the study, improving teacher performance in the learning process, through coaching Academic supervision the results are very good. This was evident at the first meeting of the 5 teachers who were present at the time of the study the average grade reached; $65.50 \%$ increased to $83.75 \%$. From the analysis of the data above, teacher development by the school principal through Academic supervision is effectively implemented in an effort to improve teacher performance achievements, which means that the process of developing school principals is more successful and can improve teacher performance in the learning process, particularly SMP Negeri 3 Kuala Mandor B, Kubu Raya Regency. It is therefore expected that principals can carry out coaching through ongoing academic supervision..
\end{abstract}

\section{Keywords: Performance, Learning, Academic Supervision}

\section{PENDAHULUAN}

Keterampilan utama dari seorang guru adalah melakukan penilaian dan pembinaan kepada siswa untuk secara terus menerus meningkatkan kualitas proses pembelajaran yang dilaksanakan di kelas agar berdampak pada kualitas hasil belajar siswa. Untuk dapat mencapai kualitas tersebut guru diharapkan dapat melakukan pembelajaran yang didasarkan pada metode dan teknik yang tepat sesuai dengan kebutuhan siswa.

Namun kenyataan di lapangan menunjukkan bahwa ternyata kualitas pendidikan masih jauh dari apa yang diharapkan terutama di SMP Negeri 3 Kuala Mandor B Kabupaten Kubu Raya. Untuk mengatasi masalah tersebut maka peneliti sekaligus sebagai kepala sekolah melakukan pembinaan kepada guru melalui supervisi Akademik, dan tindakan ini sebagai suatu langkah yang tepat agar peningkatan capaian kinerja guru dapat dicapai sesuai dengan program pemerintah yaitu program pendidikan berkinerja.

Kepala sekolah sebagai penanggung jawab peningkatan Kinerja pendidikan di SMP Negeri 3 Kuala Mandor B Kabupaten Kubu Raya sebagai pembina menyadari bahwa tugas ini cukup berat, dan ketrampilan yang dibutuhkan cukup kompleks. Bidang pengawasan instruksional dihadapkan pada kebutuhan yang amat penting dalam membantu guru agar dapat berkembang dengan pesat dalam pengelolaan kelas. Kompleksitas sekolah memaksa begitu banyak cara harus disiapkan guru dalam proses pembelajaran. Bayangkan, di masa mendatang seseorang setelah sarjana baru mendapatkan kualifikasi sebagai pengajar setelah lulus dari Pendidikan Profesi Guru (PPG). Dengan demikian profesi pengawas menjadi lebih berat dan kompleks dengan tingkat ketrampilan yang harus lebih tinggi dari guru yang telah lulus PPG. Oleh karena itu Pengawas bekerja lebih dari sekedar mengamati guru di dalam kelas; mereka melibatkan guru dalam rentang kegiatan yang lebih luas yang fokus pada pembelajaran. Kegiatan ini terkait dengan pengembangan professional dari usaha-usaha pengawasan.

Peningkatan capaian Kinerja guru melalui prestasi belajar adalah hasil atau akibat dari kegiatan belajar.Untuk mengetahui tentang prestasi belajar perlu dijelaskan tentang hakekat belajar. 
Belajar merupakan suatu proses yang dilakukan seseorang untuk memperoleh suatu perubahan tingkah laku yang baru secara keseluruhan, sebagai hasil pengalaman dan ini dikemukakan oleh Slameto (1991:77). Dimana perubahan itu bersifat kontinyu dan fungsional, terjadi secara sadar, bersifat positif dan aktif,bukan bersifat sementara, bertujuan atau terarah, dan mencakup seluruh aspek tingkah laku yang selanjutnya dinamakan hasil belajar.Dan hasil belajar tersebut dapat dinyatakan dalam bentuk prestasi belajar, sebagai capaian mut sekolah.

Menurut Richard (2007:56), belajar adalah suatu proses usaha yang dilakukan individu untuk memperoleh suatu perubahan tingkah laku yang baru secara keseluruhan sebagai hasil pengalaman individu itu sendiri dalam interaksinya dengan lingkungan.

Berdasarkan pengertian prestasi belajar di atas, maka dapat didefinisikan tentang prestasi belajar, yaitu tingkat keberhasilan yang dicapai siswa berupa ketrampilan dan pengetahuan berdasarkan hasil tes atau evaluasi setelah pelaksanaan proses belajar mengajar.

Istilah kemampuan mengajar guru merupakan kemampuan guru dalam menigkatkan kinerjanya melaksanakan pembelajaran di kelas. Kinerja dapat diterjemahkan dalam perfomance atau unjuk kerja, artinya kemampuan yang ditampilkan seseorang terhadap pekerjaannya pada tempat ia bekerja. Kinerja merupakan suatu kinerja yang esensial terhadap keberhasilan suatu pekerjaan. Karena itu suatu kinerja yang efektif bagi setiap individu perli diciptakan sehingga tujuan lembaga dapat tercapai secara optimal.

Menurut Fattah (1996:66) kinerja diartikan sebagai ungkapan kemajuan yang didasari oleh pengetahuan, sikap, keterampilan dan otivasi dalam menghasilkan suatu pekerjaan. Dengan demikian dapat disimpulkan bahwa kinerja adalah hasil kerja seseorang yang mencerminkan prestasi kerja sebagai ungkapan pengetahuan, sikap dan keterampilan.

Lebih lanjut Hamalik (2013:34) kemampuan dasar yang disebut juga kinerja dari seorang guru teridiri dari: (1) kemampuan merencanakan pembelajaran, (2) kemampuan mengelola program belajar mengajar, (3) kemampuan menglola kelas (4) kemampuan menggunakan media/sumber belajar, (5) kemampuan menglola interaksi belajar mengajar, (6) mampu melaksanakan evaluasi belajar siswa.

Supervisi Akademik yang juga disebut supervisi kelas adalah suatu bentuk bimbingan atau bantuan profesional yang diberikan kepada guru berdasarkan kebutuhan guru melalui siklus yang sistematis untuk meningkatkan proses belajar mengajar.

Menurut J.J.Bellon (1985:77) istilah Akademik menunjuk kepada unsur-unsur khusus sebagai berikut: (1) Adanya hubungan tatap muka antara supervisor dan guru dalam proses supervisi; (2) Proses supervisi difokuskan pada unjuk kerja mengajar guru di kelas; (3) data unjuk kerja mengajar diperoleh melalui observasi secara cermat; (4) Data dianalisis bersama anatar supervisor dan guru; (5) Supervisor dan guru bersama-sama menilai dan mengambil kesimpulan unjuk kerja mengajar guru; (6) Fokus observasi sesuai dengan kebutuhan dan atau permintaan guru yang bersangkutan.

Dari berbagai pendapat analisis dan uraian di atas, dapat disimpulkan, bahwa supervisi Akademik adalah supervisi yang memiliki ciri-ciri esensial sebagai berikut: (1) Bimbingan dari supervisor kepada guru bersifat bantuan, bukan perintah atau instruksi, sehingga prakarsa dan tanggungjawab pengembangan diri berada di tangan guru; (2) Hubungan interaksi dalam proses supervisi bersifat kolegial, sehingga intim dan terbuka; (3) Meskipun unjuk kerja mengajar guru di kelas bersifat luas dan terintegrasi, tetapi sasaran supervisi terbatas pada apa yang dikontrakkan; (4) Sasaran supervisi diajukan oleh guru, dikaji dan disepakati bersama dalam kontrak; (5) Proses supervisi Akademik melalui tiga tahapan: pertemuan pendahuluan, observasi kelas, dan pertemuan balikan; (6) Instrumen observasi ditentukan bersama oleh guru dan supervisor; (7) Balikan yang objektif dan sepesifik diberikan dengan segera; (8) Analisis dan interpretasi data observasi dilakukan bersama-sama; (9) Proses supervisi bersiklus.

\section{METODE PENELITIAN}

Subyek dalam penelitian ini adalah Guru SMP Negeri 3 Kuala Mandor B Kabupaten Kubu Raya yang merupakan tempat peneliti bertugas sebagai kepala sekolah. Penelitian dilaksanakan dalam 2 siklus. Kegiatan dilaksanakan dalam semester ganjil tahun pelajaran 2019-2020. Lama penelitian 4 pekan efektif dilaksanakan mulai tanggal 09 September sampai dengan 14 Oktober 2019. Dalam pelaksanaan tindakan, rancangan dilakukan dalam 2 siklus yang meliputi; (a) perencanaan, (2) tindakan, (3) pengamatan, (4) refleksi. Dalam pengumpulan data, teknik yang digunakan adalah menggunakan observasi dan dokumentasi. Penelitian tindakan sekolah yang dilaksanakan dalam dua siklus ini dianggap sudah berhasil 
apabila terjadi peningkatan kinerja guru mencapai $85 \%$ guru telah mencapai ketuntasan dengan nilai rata-rata 75. Jika peningkatan tersebut dapat dicapai pada tahap siklus 1 dan 2, maka siklus selanjutnya tidak akan dilaksanakan karena tindakan sekolah yang dilakukan sudah dinilai efektif sesuai dengan harapan dalam manajemen berbasis sekolah ( MBS ).

\section{Tahap Persiapan}

Penelitian ini menggunakan model pembinaan melalui supervisi Akademik. Tujuan yang diharapkan pada pertemuan pertama dalam pembinaan kepala sekolah melalui supervisi Akademik ini adalah peningkatan Kinerja guru dalam proses belajar mengajar. Agar tercapai tujuan di atas, peneliti yang bertindak sebagai kepala sekolah dengan melakukan langkahlangkah sebagai berikut; (1). Menyusun instrumen pembinaan; (2). Menyusun Instrumen Monitoring; (3). Sosialisasi kepada guru; (4). Melaksanakan tindakan dalam pembinaan; (5). Melakukan refleksi; (6). Menyusun strategi pembinaan pada siklus ke dua berdasar refleksi siklus pertama; (7). Melaksanakan pembinaan pada siklus kedua; (8). Melakukan Observasi; (9). Melakukan refleksi pada siklus kedua.

\section{Tahap Pelaksanaan}

Pelaksanaan tindakan dalam penelitian dilakukan 2 siklus yang terdiri dari empat kali pertemuan. Waktu yang digunakan setiap kali pertemuan adalah 2 x 40 menit. Siklus pertama dilaksanakan pada tanggal 9 s.d 16 September 2019 dan siklus kedua pada tanggal 7 s.d 14 Oktober 2019. Penelitian tindakan sekolah ini dilaksanakan pada saat kegiatan belajar mengajar di sekolah.

\section{Siklus 1}

Tahap Perencanaan. Pada tahap ini peneliti mempersiapkan perangkat pembinaan yang terdiri dari rencana pembinaan, soal tes formatif 1 dan alat-alat pembinaan lain yang mendukung. Selain itu juga dipersiapkan lembar observasi peningkatan Kinerja guru dalam proses belajar mengajar dengan melalui pembinaan supervisi Akademik kepala sekolah.

Tahap Kegiatan dan Pelaksanaan. Pelaksanaan kegiatan pembinaan untuk siklus I dilaksanakan pada tanggal 09 s.d 16 September 2019 di SMP Negeri 3 Kuala Mandor B tahun pelajaran 2019-2020. Dalam hal ini peneliti bertindak sebagai kepala sekolah. Adapun proses pembinaan mengacu pada rencana pembinaan yang telah dipersiapkan.

Pengamatan (observasi) dilaksanakan bersamaan dengan pelaksanaan pembelajaran. Pada akhir proses pembinaan guru diberi penilaian formatif I dengan tujuan untuk mengetahui tingkat pemahaman guru dalam meningkatkan Kinerja guru dalam proses belajar mengajar sesuai dengan yang telah dilakukan. Adapun data hasil penelitian pada siklus I. adalah seperti pada tabel berikut :

Tabel 1. Distribusi Nilai Pembinaan Kepala Sekolah pada Siklus 1

\begin{tabular}{|c|c|c|c|c|}
\hline \multirow{2}{*}{ No } & \multirow{2}{*}{ Nama Guru } & \multirow{2}{*}{ Skor } & \multicolumn{2}{|c|}{ Keterangan } \\
\hline & & & Tuntas & Tidak Tuntas \\
\hline 1 & $\begin{array}{l}\text { Yanuri, S.Pd } \\
\text { NIP. } 197012202009031002\end{array}$ & 70 & $\sqrt{ }$ & \\
\hline 2 & $\begin{array}{l}\text { Cornenila, S.P } \\
\text { NIP. } 197906202009032003\end{array}$ & 60 & & $\sqrt{ }$ \\
\hline 3 & $\begin{array}{l}\text { Isni Awaliyah, S.Pd } \\
\text { NIP. } 198703092010012010\end{array}$ & 64 & & $\sqrt{ }$ \\
\hline 4 & $\begin{array}{l}\text { Halijah, S.Sos } \\
\text { NIP. } 197709222017102001\end{array}$ & 75 & $\sqrt{ }$ & \\
\hline 5 & Erva Arwina Sitepu, S.Pd & 60 & & $\sqrt{ }$ \\
\hline Jum & hotal & 329 & - & - \\
\hline
\end{tabular}

Keterangan :

Jumlah Guru yang tuntas $\quad: 2$ Orang

Jumlah Guru yang belum tuntas : 3 Orang

Dari tabel di atas dapat dijelaskan bahwa dengan pembinaan yang dilakukan oleh kepala sekolah melalui supervisi Akademik diperoleh nilai rata-rata peningkatan Kinerja guru adalah $65,50 \%$ atau baru 2 dari 5 orang guru sudah tuntas. Hasil tersebut menunjukkan bahwa pada siklus pertama secara kelompok ( sekolah ) belum meningkat muitunya daam proses belajar mengajar, karena yang memperoleh nilai $\geq 65$ 
hanya sebesar 37,50\% lebih kecil dari persentase ketuntasan yang dikehendaki yaitu sebesar $85 \%$. Hal ini disebabkan karena banyak guru yang belum memahami dan merasa baru dengan supervisi Akademik sehingga mereka belum dapat memahaminya dengan baik..

Dalam pelaksanaan kegiatan pembinaan diperoleh informasi dari hasil pengamatan sebagai berikut; (1). Kepala sekolah masih kurang teliti dalam melakukan pembinaan di sekolah. (2). Kepala sekolah masih kurang baik dalam pemanfaat waktu. (3). Kepala sekolah Sekolah masih kurang konsentrasi dalam melakukan pembinaan, karena ada tugas lain yang harus dikerjakan.

Pelaksanaan kegiatan pembinaan pada siklus 1 ini masih terdapat kekurangan, sehingga perlu adanya revisi untuk dilakukan pada siklus berikutnya; (1). Kepala sekolah perlu lebih terampil dalam memotivasi guru dan lebih jelas dalam menyampaikan tujuan pembinaan. Dimana guru diajak untuk terlibat langsung dalam setiap kegiatan yang akan dilakukan. (2). Kepala sekolah perlu mendistribusikan waktu secara baik dengan menambahkan informasi-informasi yang dirasa perlu dan memberi catatan. (3). Kepala sekolah harus lebih terampil dan bersemangat dalam memotivasi guru sehingga Kinerjanya dalam proses belajar mengajar lebih meningkat.

\section{Siklus 2}

Tahap Perencanaan. Pada tahap ini peneliti mempersiapkan perangkat pembinaan yang terdiri dari rencana pembinaan 2 , soal tes formatif 2 dan alat-alat pembinaan lainnya yang mendukung.

Tahap kegiatan dan pengamatan. Pelaksanaan kegiatan belajar mengajar untuk siklus II dilaksanakan pada tanggal 07 s.d 14 Oktober 2019 di SMP Negeri 3 Kuala Mandor B Kabupaten Kubu Raya tahun pelajaran 2019-2020 dengan jumlah 5 orang guru. Dalam hal ini peneliti bertindak sebagai kepala sekolah. Adapun proses pembinaaan mengacu pada rencana pembinaan dengan memperhatikan revisi pada siklus I, sehingga kesalahan atau kekurangan pada siklus I tidak terulang lagi pada siklus II. Pengamatan (observasi) dilaksanakan bersamaan dengan pelaksanaan proses belajar mengajar berlangsung.

Pada akhir proses pembinaan guru diberi penilaian formatif II dengan tujuan untuk mengetahui tingkat Kinerja guru dalam melaksanakan tugasnya yang telah dilakukan. Instrumen yang digunakan adalah tes formatif II. Adapun data hasil penelitian pada siklus II adalah sebagai berikut

Tabel 2. Distribusi Nilai Pembinaan Kepala Sekolah pada Siklus 2

\begin{tabular}{|c|c|c|c|c|}
\hline \multirow{2}{*}{ No } & \multirow{2}{*}{ Nama Guru } & \multirow{2}{*}{ Skor } & \multicolumn{2}{|c|}{ Keterangan } \\
\hline & & & Tuntas & Tidak Tuntas \\
\hline 1 & $\begin{array}{c}\text { Yanuri, S.Pd } \\
\text { NIP. } 197012202009031002\end{array}$ & 95 & $\sqrt{ }$ & \\
\hline 2 & $\begin{array}{c}\text { Cornenila, S.P } \\
\text { NIP. } 197906202009032003\end{array}$ & 85 & $\sqrt{ }$ & \\
\hline 3 & $\begin{array}{c}\text { Isni Awaliyah, S.Pd } \\
\text { NIP. } 198703092010012010\end{array}$ & 75 & $\sqrt{ }$ & \\
\hline 4 & $\begin{array}{c}\text { Halijah, S.Sos } \\
\text { NIP. } 197709222017102001\end{array}$ & 85 & $\sqrt{ }$ & \\
\hline 5 & Erva Arwina Sitepu, S.Pd & 75 & $\sqrt{ }$ & \\
\hline & Jumlah Total & 415 & - & - \\
\hline
\end{tabular}

Keterangan :

Jumlah Guru yang tuntas : : 5 Orang

Jumlah Guru yang belum tuntas : - Orang

Berdasarkan tabel di atas diperoleh nilai ratarata tes formatif sebesar $83,75 \%$ dan 8 orang guru sudah mencapai ketuntasan dalam meningkatkan Kinerjanya dalam proses belajar mengajar. Maka secara kelompok ketuntasan telah mencapai $100 \%$ ( termasuk kategori tuntas). Hasil pada siklus II ini mengalami peningkatan lebih baik dari siklus I.
Adanya peningkatan hasil belajar pada siklus II ini dipengaruhi oleh adanya peningkatan kemampuan kepala sekolah dalam menerapkan pembinaan melalui supervisi Akademik sehingga guru menjadi lebih memahami tugasnya sehingga dapat meningkatkan Kinerja dalam proses belajar mengajar di kelas. Di samping itu ketuntasan ini juga dipengaruhi oleh kerja sama dari guru dengan kepala sekolah dalam melaksanakan tugasnya masing masing. 
Refleksi. Pada tahap ini akan dikaji apa yang telah terlaksana dengan baik maupun yang masih kurang baik dalam proses pembinaan melalui supervisi Akademik. Dari data-data yang telah diperoleh dapat duraikan sebagai berikut; (1). Selama proses pembinaan kepala sekolah telah melaksanakan semua pembinaan dengan baik. Meskipun ada beberapa aspek yang belum sempurna, tetapi persentase pelaksanaannya untuk masing-masing aspek cukup besar. (2). Berdasarkan data hasil pengamatan diketahui bahwa guru aktif selama proses pembinaan berlangsung. (3). Kekurangan pada siklus-siklus sebelumnya sudah mengalami perbaikan dan peningkatan sehingga menjadi lebih baik. (4). Hasil pembinaan guru oleh kepala sekolah melalui supervisi Akademik pada siklus II mencapai ketuntasan.

\section{Tahap Akhir}

Pada siklus II kepala sekolah telah melaksanakan pembinaan dengan baik dan dilihat dari peningkatan capaian Kinerja guru, pelaksanaan pembinaan sudah berjalan dengan baik. Maka tidak diperlukan revisi terlalu banyak, tetapi yang perlu diperhatikan untuk tindakan selanjutnya adalah memaksimalkan dan mempertahankan apa yang telah ada dengan tujuan agar pada pelaksanaan pembinaan selanjutnya baik melalui supervisi Akademik maupun supervisi Akademik dapat meningkatkan capaian Kinerja guru sehingga tujuan pembinaan sebagai upaya meningkatkan Kinerja pendidikan dapat tercapai.

\section{HASIL PENELITAN DAN PEMBAHASAN Hasil}

Setelah dilakukan tindakan pada siklus 1 dan 2 menunjukkan hasil sebagai berikut:

Tabel 3. Hasil Tes Terhadap Peningkatan Kinerja Guru

\begin{tabular}{clcc}
\hline No & \multicolumn{1}{c}{ Nama Guru } & Siklus 1 & Siklus 2 \\
\hline 1 & $\begin{array}{l}\text { Yanuri, S.Pd } \\
\text { NIP. 197012202009031002 }\end{array}$ & 70 & 95 \\
\hline 2 & $\begin{array}{l}\text { Cornenila, S.P } \\
\text { NIP. 197906202009032003 }\end{array}$ & 60 & 85 \\
\hline 3 & $\begin{array}{l}\text { Isni Awaliyah, S.Pd } \\
\text { NIP. 198703092010012010 }\end{array}$ & 64 & 75 \\
\hline 4 & $\begin{array}{l}\text { Halijah, S.Sos } \\
\text { NIP. 197709222017102001 }\end{array}$ & 75 & 85 \\
\hline 5 & Erva Arwina Sitepu, S.Pd & 60 & 75 \\
\hline \multicolumn{2}{l}{ Jumlah Total } & 329 & 415 \\
\hline
\end{tabular}

Dari hasil analisis tersebut dapat disimpulkan bahwa terjadi peningkatan Kinerja guru dalam proses pembelajaran setelah diberi pembinaan melalui supervisi Akademik yaitu peningkatan dari $65,50 \%$ menjadi $83,75 \%$ ada kenaikan sebesar $18,25 \%$.

\section{Pembahasan}

Ketuntasan Hasil Pembinaan Kepada Guru. Melalui hasil peneilitian ini menunjukkan bahwa pembinaan melalui supervisi Akademik memiliki dampak positif dalam meningkatkan Kinerja guru dalam proses pembelajaran, hal ini dapat dilihat dari semakin mantapnya pemahaman guru dan terhadap pembinaan yang disampaikan kepala sekolah (Kinerja guru dalam proses pembelajaran meningkat dari siklus I dan II ) yaitu masingmasing $65,50 \%$ dan $83,75 \%$.

Kemampuan kepala sekolah dalam meningkatkan Kinerja guru dalam proses pembelajaran adalah berdasarkan analisis data, diperoleh aktivitas guru dalam meningkatkan Kinerja guru dalam proses pembelajaran pada setiap siklus mengalami peningkatan. Hal ini berdampak positif terhadap capaian Kinerja guru, yaitu dapat ditunjukkan dengan meningkatnya nilai rata-rata guru pada setiap siklus yang terus mengalami peningkatan.

Aktivitas Kepala Sekolah dalam Pembinaan melalui Supervisi Akademik adalah berdasarkan analisis data, diperoleh aktivitas guru, yang paling dominan dalam kegiatan supervisi Akademik adalah bekerja dengan menggunakan alat/media, mendengarkan/memperhatikan penjelasan kepala sekolah, dan diskusi antar guru dan kepala sekolah. Jadi dapat dikatakan bahwa aktivitas guru dapat dikategorikan aktif. Sedangkan untuk aktivitas kepala sekolah selama pembinaan telah melaksanakan langkah-langkah metode pembinaan 
melalui supervisi Akademik dengan baik. Hal ini terlihat dari aktivitas guru yang muncul di antaranya aktivitas membuat dan merencanakan program sekolah, melaksanakan, memberi umpan balik/evaluasi/tanya jawab di mana prosentase untuk aktivitas di atas cukup besar.

Berdasarkan hasil penelitian di atas, peningkatan Kinerja guru dalam proses pembelajaran, melalui pembinaan supervisi Akademik hasilnya sangat baik. Hal itu tampak pada pertemuan pertama dari 5 orang guru yang ada pada saat penelitian ini dilakukan nilai rata rata mencapai ; 65,50 \% meningkat menjadi 83,75\% .

Berdasarkan Undang-undang Nomor 20 Tahun 2003 tentang kompetensi guru dan kepala sekolah, dan dapat membuat rencana kerja kerja sekolah, serta dapat mengorganisasikan sekolah kearah perubahan yang diinginkan mencapai $85 \%$ ketercapaiannya, maka supervisi Akademik tersebut dikatakan efektif. Dengan demikian maka hipotesis yang diajukan di atas dapat diterima.

\section{SIMPULAN DAN SARAN Simpulan}

Berdasarkan analisis hasil penelitian dan diskusi dapat disimpulkan sebagai berikut; (1). Pembinaan kepala sekolah dalam upaya meningkatkan Kinerja guru dalam proses pembelajaran melalui supervisi Akademik menunjukan peningkatan pada tiap-tiap putaran (Siklus). (2). Aktivitas dalam kegiatan pembinaan menunjukan bahwa guru dapat meningkatkan Kinerja guru dalam proses pembelajaran, dengan baik dalam setiap aspek. (3). Peningkatan Kinerja guru dalam proses pembelajaran oleh kepala sekolah melalui supervisi Akademik ini menunjukan peningkatan pada tiap-tiap putarannya. (4). Aktivitas guru menunjukan bahwa kegiatan pembinaan melalui supervisi Akademik bermanfaat dan dapat membantu meningkatkan Kinerja guru dalam proses pembelajaran, untuk lebih muda memahami konsep peran dan fungsi guru sehingga kinerja guru dapat meningkat, dengan demikian capaian Kinerja guru dapat ditingkatkan.

\section{Saran}

Berdasarkan hasil penelitian dapat diajukan beberapa saran sebagai berikut; (1). Penelitian perlu dilanjutkan dengan serangkaian penelitian yang mengembangkan alat ukur keberhasilan yang lebih reliabel agar dapat menggambarkan peningkatan capaian Kinerja guru dengan baik sehingga Kinerja pendidikan dapat ditingkatkan. (2). Pembinaan kepala sekolah melalui supervisi Akademik kepala sekolah dalam upaya meningkatkan capaian Kinerja guru diperlukan perhatian penuh dan disiplin yang tinggi pada setiap langkah pembinaan,dan perencanaan yang matang misalnya dalam pengalokasian waktu dan pemilihan konsep yang sesuai. (3). Kepada guru diharapkan selalu mengikuti perkembangan jaman, terutama dengan membaca hasil karya para ahli sehingga tidak ketinggalan dengan daerah lain, dalam meningkatkan Kinerja pendidikan,sebagai tanggung jawab bersama memajukan pendidikan.

\section{DAFTAR RUJUKAN}

Arends Richard I. (2007). Learning to Teach. Seventh edition. New York:McGraw Hill Companies.

Bellon, J. J., \& Bellon,E. C. (1985). Classroom supervision and instructional improvement : A synergetic process (2nd ed.). Dubuque, IA: Kendall/Hunt.

Depdiknas RI, 2003 Undang Undang Nomor 20 Tentang Sistem Pendidikan Nasional.Jakarta : depdiknas

Fattah, Nanang, (1996) Landasan Manajemen Pendidikan, Bandung: PT Remaja. Rosdakarya.

Hamalik,Oemar.(2013). Proses Belajar Mengajar, Jakarta: PT.Bumi Aksara.

Slameto (1991). Belajar dan Faktor yang Mempengaruhinya. Jakarta : Rineka. Cipta. Sudjana 